Tranchenko L. V., Tereshchuk N. V., Lopatiuk R. I., Tranchenko O. M. Use of information support for marketing in tourist enterprises. Journal of Education, Health and Sport. 2021;11(2):200-207. eISSN 2391-8306. DOI http://dx.doi.org/10.12775/JEHS.2021.11.02.020

https://apcz.umk.pl/czasopisma/index.php/JEHS/article/view/JEHS.2021.11.02.020

https://zenodo.org/record/4958675

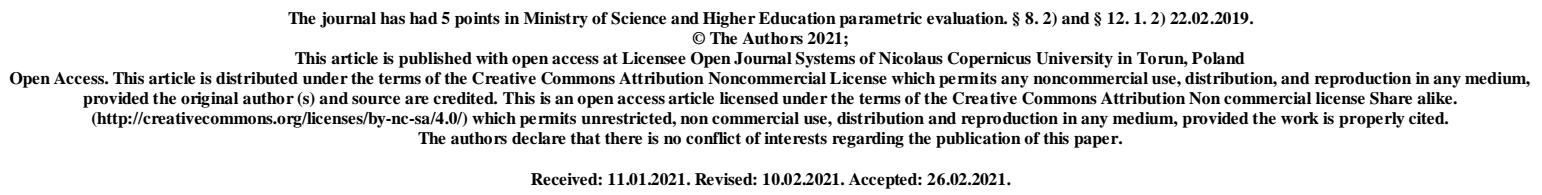

\title{
USE OF INFORMATION SUPPORT FOR MARKETING IN TOURIST ENTERPRISES
}

\author{
L. V. Tranchenko ${ }^{1}$, N. V. Tereshchuk ${ }^{1}$, R. I. Lopatiuk ${ }^{2}$, O. M. Tranchenko ${ }^{1}$ \\ ${ }^{1}$ Uman National University of Horticulture \\ ${ }^{2}$ Vinnytsia National Agrarian University
}

\begin{abstract}
Every year Ukraine integrates more and more into the world economic economy. Tourist services are one of the most important socio-economic sectors of the world economy. However, Ukraine, having a variety of tourism resources, has little experience in this area. For these reasons, the relevance of the article on the promotion of tourist services is determined. The article investigates the means of promoting tourist services, determining the theoretical and methodological principles of building an effective process of marketing communications at the enterprises of the tourist sphere. It is proved that in order to achieve the effect of synergy, the main principle when deciding on the use of several means of communication is the choice of one means as the main and several - auxiliary. The main thing is to be able to independently and effectively influence consumers. Auxiliary - should fill possible gaps in the reach of the target audience, supporting the main means of communication.
\end{abstract}

Key words: tourism; tourist activity; tourist firms; marketing; digital communications; information technologies; information support.

Analysis of recent research and publications. Publications of such scientists as Dibrova TG, Putzenteilo PR, Voskolovich NA, Braimer RA and others are devoted to the 
problems of marketing of the tourist sphere and in particular to the problem of strategic planning and means of promotion of tourist services. [1-4]. However, in these publications not enough attention is paid to the integration of marketing communications of tourism enterprises with consumers, which is a necessary condition for successful business. Thus, the purpose of the article is: 1) research of means of promotion of tourist services; 2) determination of theoretical and methodical bases of construction of effective process of marketing communications at the enterprises of tourist sphere.

Presenting main material. Integrated Marketing Communications is a concept of marketing communications planning based on the need to assess the strategic role of each of its elements (advertising, sales promotion, PR, personal sales, etc.) in the promotion strategy, finding their optimal combination to ensure a clear and consistent the impact of the company's communication programs to promote a particular brand [1].

Here are the main components of integrated marketing communications: advertising; sales promotion; PR (public relations); personal sale; merchandising; direct marketing; sponsorship marketing; exhibitions. The integration of marketing communications increases the importance of the promotion complex. This allows you to maintain a single positioning within each target segment, communication tools reinforce each other and create a synergy effect.

The synergy is manifested in the fact that the effect of integrated application of means of communication (integrated communications) differs from the simple addition of effects from the use of each means separately. It is well known that services, including tourism, are much more difficult to sell than goods. The main characteristics that should be considered when developing marketing programs for the sale of services are the following: insensitivity; inseparability from the source of service; inconsistency of quality; inability to save.

These characteristics must be taken into account when developing and planning a promotion strategy. The promotion strategy should be based on the behavior of service consumers. Compared to consumers of goods in kind, consumers of services in the stage of searching for information rely more on information obtained from personal sources. Price and material environment are for the consumer the main sources of decision-making about the quality of service. The desired set of potential firms when choosing services to buy is usually much smaller than for goods. When buying services, the consumer feels a greater risk of being dissatisfied. Consumers of services find it harder to get used to and accept new services, but much more loyal and loyal to their favorite brand compared to manufactured goods. Consumers of services feel guilty if they are not satisfied with the quality of service, and for 
this reason much less often express their dissatisfaction with the quality of service, which, in turn, creates a problem of quality control. You need to more precisely define the target audience for advertising messages. Students and seniors can buy toothpaste and washing powder without "interfering" with each other.

However, being together on a tourist trip, in a hotel, at a concert or in a restaurant, these two segments can significantly affect the perception of the service. In the first case there is no need to separate segments, in the second - it exists. Accordingly, in the first case, the advertising message may have a general form, in the second - must be selective. When planning a promotion strategy, you need to include your company's staff in the secondary target audience. Services are usually provided by contact staff. When staff see themselves in advertising the services they provide, they experience a sense of pride for their work and company. A sense of pride is a significant motivating factor, which, in turn, significantly affects the work of staff and, consequently, the quality of services provided to the end user.

This task is partially solved by developing an internal marketing strategy aimed at motivating staff. The interactive interaction between staff and consumers should be emphasized. A service as a commodity, in essence, is the interaction of staff and the customer, leading to a certain result. Demonstrating how both parties achieve it is a compelling motivating factor for staff and a buying motive for the consumer. It is necessary to influence the opinion of consumers that the provision of services in the firm is stable regardless of time and place. It is recommended to emphasize the advantages of their three "Pi" (service process, material environment and staff) compared to competitors. They form the uniqueness and distinctive features of the service offered to the market. This problem can be solved with the help of thoughtful positioning of the service or company in the eyes of the consumer.

If the emphasis is on quality, it is necessary to emphasize the criteria of quality of your service: material elements, reliability, conviction, compassion and sensitivity. You should not overestimate your advertising promises, which largely shape consumer expectations. This leads to consumer dissatisfaction and distrust. In turn, consumer dissatisfaction is the reason for his departure from competitors, and distrust leads to the need to increase the number of funds to attract consumers. Interestingly, with the help of advertising it is possible to underestimate consumer expectations. This maneuver allows you to easily confirm and even exceed consumer expectations. When planning a promotion strategy, many workers in the tourism industry perceive promotion as a supplement to advertising. Only in some cases, 
certain communication tools are used separately from the marketing plan (each of them has its place in the plan), even if they pursue different goals.

Advertising is often seen as the main means to achieve a long-term goal, as well as to create an image of the organization and its product, while promotion is used to perform shortterm tasks, such as getting rid of current stocks. Although this attitude towards marketing is based on the excessive use of advertising in the past as a means of communication, now the decisive factor is increased competition in the tourism industry, which forces marketing managers to be more precise in using all available communication methods.

There are hundreds of types of promotion tools that can be classified as tools aimed at: staff of companies (for sales representatives) with the help of various incentives (financial, incentive travel, etc.); bonuses; competitions and contests; dealers and retailers (travel agents) through: issue souvenirs with company symbols (calendars, notebooks, pens, ashtrays); trade exhibitions; product presentations (business lunches, dinners, etc.); correspondence (letters, circulars, etc.); joint promotion schemes (organizational or financial assistance); customers directly or through a retailer) through: computer display, Internet, wall screens, posters, brochures, etc; souvenirs (handbags with the name of the company, covers for storing tickets, etc.); providing hotels with soaps, shampoos, special shower caps, and "necessary" customers - flowers and fruits; financing with a moderate interest rate; providing free vouchers; organization of joint promotion activities with companies in other areas of business (incentive travel for company employees, travel accompanied by preferential purchases of goods and services). These promotion tools are mainly designed to create a good attitude of customers to the company and the proposed travel product, as well as its memorization, which can increase the value of the product.

When selling a product to retailers, marketing managers can use one of two strategies. The first is called the "pull-out" strategy and aims to promote the product directly to the consumer, creating demand through extensive familiarity with the company's brand, thus forcing the customer to buy the product from retailers. In this case, the customer can make a purchase decision in advance, and retailers must have as many products as needed to meet demand. The second strategy is called the "push" strategy and is designed to activate retailers. With this strategy, retailers are persuaded to follow a plan to sell tourism products and help them sell [1]. For example, new travel companies (tour operators) in creating their market, on the one hand, can use the first strategy of "pulling", supporting it with advertising, and on the other hand, can use the second strategy of "pushing", selecting key retailers and helping them. when selling the product to its customers, while distributing the costs of promotion evenly. 
Consider in more detail some of the methods of promoting travel services. One of the important methods is the organization of exhibitions that allow sellers and buyers of a tourist product to meet in the common area and conclude transactions. The largest and most popular are exhibitions held in London and Berlin. As a rule, exhibitions are divided into three types, which are aimed at: society as a whole, travel companies and participants by special invitations. Some events (for example, the World Travel Market in London) are open only to travel companies and perform more social functions than commercial ones. At these exhibitions, travel agencies have the opportunity to increase their knowledge of tourism products offered by national and local tourism organizations, and at the same time present their own product, as well as their country or region, showing films and national costumes, inviting folk ensembles, wine tastings and etc. Interest in the exhibition is increasing due to the active participation of the press. The exhibition also organizes symposia and meetings on various topics relevant to the tourism industry [3].

However, despite all the advantages, participation in such exhibitions is expensive for its participants, who have to pay rent for the occupied space, design of the stand, equipment, handouts, etc. For the sake of prestige, large companies seek to occupy large areas in good places. The staff of the companies participating in the exhibition establishes contacts with the organizers of exhibitions long before its beginning (more often it takes almost a year to prepare such exhibitions). In some cases, contrary to expectations, attendance at the exhibition may be low. However, high attendance does not always justify the high cost of participating in the exhibition. For this reason, many exhibitors should be satisfied with the exhibition primarily as an advertising event, rather than as a promotion of their product. The purpose of marketing exhibition organizers is to reduce the cost of their holding.

The organizers, for their part, are obliged to provide participants with information about the expected number of visitors and at the same time to assess the number of participants who want to visit a particular stand. It is estimated that each seller can serve an average of 12-15 requests and needs about $5 \mathrm{~m} 2$ to receive visitors. Next, the size of the stand is estimated based on the number of staff serving the stand, and the area for materials (it is necessary to take into account the area for negotiations, and for the reception of important guests). Another important method of promotion in the tourism industry is a presentation, which is defined as an action aimed at asserting oneself or gaining popularity. Presentations are often used by travel companies to present their programs or products to travel agencies. Sometimes these activities take the form of formal conversations between senior sales managers and relevant travel agency staff about new programs and products. Such meetings 
are useful for the company not only as a means of promoting its product, but also to get firsthand information about the market.

Formal conversations during presentations are also accompanied by a demonstration of videos. Advertising is the most important element of the communication complex. It has a great potential impact on all other elements of this complex (can attract large masses of people) and is the most expensive [4]. Playing a major role in the entire communication system, advertising simultaneously informs about the company and its product, persuades potential buyers to stop their choice on the company and its product, strengthens the confidence of existing customers in the correctness of their choice, etc. In the tourism business, advertising performs the following important tasks: 1 . With its help, any component of the service must have a tangible appearance so that the potential consumer understands what is being offered to him. 2. It must promise a benefit or a solution to the problem. 3. It must indicate the differences between the company's product and the product of its competitors. 4. It should have a positive impact on those employees of the company who implement the promises made to customers. 5. It should be capitalized through word of mouth.

For example, the well-known hotel company "Marriott" in advertising its new service breakfast delivery to the room - fully complied with all these requirements. For example, a billboard depicting the president of the company, Bill Marriott, pointing to his watch, on the body of a waiter entering a hotel room with breakfast served on a mobile table. This advertisement made the service of timely room service tangible. At the same time, she promised to solve such an important problem for the guest as room service. The promise to serve on time, and such a promise was given by few hotels, distinguished "Marriott" from many competitors (here the company's president risked his reputation, and if the promise was not fulfilled, customers were allowed not to pay for breakfast). The advertising promise also had a positive effect on the company's employees, as it demonstrated the commitment made by the company's manager. Lastly, advertising was capitalized on by stories about Marriott's promise to even those people who had never lived in its hotels. Another form of marketing communication is direct marketing or promotion.

According to some estimates, it can affect potential customers more effectively than advertising through print media (this is due to the ability to send messages directly to its target segment) [5]. This is especially important for travel companies that do not have a wide network of businesses and cover a small market share. Sales promotion, as an element of a complex of communications, is a system of incentives designed to strengthen the feedback of 
the target audience to various activities in the marketing strategy of the travel company in general and its communication strategy in particular. Sales promotion is a means of short-term action on the market. However, the effect of sales promotion measures is achieved much faster than the use of other elements of communication. Sales promotion is used mainly to revive falling demand, increase customer awareness of the services offered, creating the image they need. A special role is played by sales promotion during the introduction of a new type of tourist service on the market.

The development of a sales promotion program is associated with solving a number of tasks: setting a sales promotion goal; choice of sales promotion tools; identification of the circle of participants; determining the intensity of measures; making decisions about the means of disseminating information about sales promotion programs; determining the duration of incentives; choice of time of events; budget development. Setting goals and choosing sales promotion tools are closely linked.

The fact is that sales promotion tools can be directed: the staff of the firm selling the services; trade intermediaries; customers. In the process of program development, the circle of participants of sales promotion is identified. This involves identifying specific segments in order to focus on specific target groups that the travel agency would like to cover with such activities. The next step is to determine the intensity of sales promotion. The effectiveness of the incentives used should be sufficient to ensure the desired level of consumption of tourism services. At the same time, it should be borne in mind that if there are too many measures, their effectiveness decreases. In order to implement the sales promotion program, it is necessary to disseminate relevant information about the planned activities. Information can be disseminated through the press, radio, television, various signs, posters, transport, etc. The next task: to determine the duration of stimulation. It is necessary, on the one hand, to give the target groups enough time to take advantage of the proposed benefits, and on the other hand to prevent excessive procrastination of measures. The effectiveness of stimulation largely depends on the choice of time.

In the practice of tourism, the time of implementation of certain incentive measures is tied to a certain season. For example, at the beginning of the holiday season, the travel agency decided to reduce the number of sales of sea cruise tickets, as this activity has become unprofitable in the last year, and specialize in family and children's recreation. The main task of the agency was to inform the target audience about the services offered, as well as to take measures to promote sales. There were advertisements in periodicals, links to the agency's website on the Internet. Family vacations in the resorts of Turkey and Bulgaria were offered 
very profitably: children under 7 traveled for free, under 14 - with a 50\% discount. "Hot" tickets were sold at a $30 \%$ discount.

Conclusions. To achieve the effect of synergy, the main principle when deciding on the use of several means of communication is the choice of one means as the main and several - auxiliary. The main thing is to be able to independently and effectively influence consumers. Auxiliary - should fill possible gaps in the reach of the target audience, supporting the main means of communication.

\section{References}

1. Dibrova T.G. Marketing policy of communications: strategies, domestic practice: Textbook - K.: "Edging house "Professional", 2009. — 320 p.

2. Putsenteilo P. R.Economics and organization of tourist and hotel entrepreneurship: Training. Pic. - K.: Center for Educational Literature, 2007. - 344 p.

3. Braimer R.A. Fundamentals of office in the Hindus of guestship: Per s. - M.: Aspect Press, 1995. - $382 \mathrm{p}$.

4. Voskolovych N.A.Marketing of tourists'services - MGU, TEIS, 2001.

5. Barnet J., Moriarty S. Marketing communique.p.), V. Kuzin (per. c. Eng.). - St. M.; H.; Mynesk: Drinkher, 2001. — 860 p. 